https://doi.org/10.18485/iipe_regbezb.2021.ch4

\title{
REZILIJENTNOST: KONCEPTUALNI OKVIR I METODOLOŠKO ORUĐE ZA OCENU I UNAPREĐENJE STANJA REGIONALNE BEZBEDNOSTI?
}

\begin{abstract}
Nevena STANKOVIĆ 1
Apstrakt: Poslednjih decenija očevidna transformacija bezbednosnih izazova, rizika i pretnji čini nužnom potrebu za rekonceptualizacijom postojećih tradicionalnih bezbednosnih paradigmi. Kao jedan od ključnih nedostataka savremenih studija bezbednosti ističe se nedostatak odgovarajućeg metodološkog instrumentarijuma za analizu, procenu i ocenu stanja bezbednosti, bilo na nivou države, regije bilo međunarodnog poretka. Jedan od frekventnijih pojmova u terminologiji različitih nauka i naučnih disciplina jeste i pojam rezilijentnosti. Korišćenje ovoga pojma u studijama bezbednosti, naročito na domaćim prostorima, tek je u začetku. Pa ipak, čini se da bi benefiti njene upotrebe, u izvesnoj meri modifikovane i prilagođene potrebama u sferi bezbednosti, bili brojni. Najpre, rezilijentnost u svojoj kvalitativnoj (deskriptivnoj) formi može poslužiti kao validan konceptualni okvir. Dalje, pokušajem njene kvantifikacije (izradom prigodnih indikatora i kreiranjem skale rezilijentnosti) potencijalno bi se mogli postići dvostruki efekti: analiza i ocena stanja bezbednosti nekoga regiona, ali i smanjenja njegove ranjivosti/ povećanja otpornosti, odnosno jačanja rezilijentnosti samog regiona na postojeće i potencijalne buduće bezbednosne rizike i krize. Upotreba rezilijentnosti kao metodološkog oruđa mogla bi se postići sintezom relevantnih sadržaja rezilijentnosti preuzetih iz različitih naučnih disciplina, sa svojim uporištem u sistemskoj teoriji, te uvođenjem novih sadržaja karakterističnih za potrebe
\end{abstract}

\footnotetext{
${ }^{1}$ Studentkinja doktorskih studija, Fakultet bezbednosti Univerziteta u Beogradu.

E-mail: stankovicnevena649@gmail.com
} 
bezbednosti, tj. proisteklih iz osobenosti savremenih regionalnih bezbednosnih izazova, rizika i pretnji.

Ključne reči: regionalna bezbednost, rezilijentnost, metodologija, ranjivost, sistemska teorija.

\section{UVODNA RAZMATRANJA}

Savremeni bezbednosni ambijent direktno je uslovljen procesom očevidne transformacije bezbednosnih izazova, rizika i pretnji, otpočetim još od perioda Hladnog rata. Decenijama unazad, svedoci smo nužne potrebe za rekonceptualizacijom postojećih bezbednosnih paradigmi. Nacionalni pristup bezbednosti, sa državom kao referentnim objektom, ostaje jedan od ključnih predmeta interesovanja akademske zajednice, uprkos činjenici da uloga i značaj države postepeno bivaju degradirani u bezbednosnom diskursu. Sa druge strane, globalni pristup bezbednosti protekom vremena privlači sve više pažnje teoretičara i praktičara bezbednosti, primarno kao pogodan analitički okvir za proveru valjanosti, kako ustaljenih, tako i novonastalih teorijskih postulata i struja. Najzad, regionalni pristup bezbednosti, čini se, biva neopravdano zanemaren i zapostavljen, iako se u posthladnoratovskom ambijentu stvara "plodno tle" za njegovo dalje razvijanje i unapređivanje.

Kao jedan od ključnih nedostataka savremenih studija bezbednosti ističe se nedostatak odgovarajućeg metodološkog instrumentarijuma za analizu i ocenu stanja bezbednosti na svim nivoima analize (nacionalnom, regionalnom ili globalnom), te samim tim i njeno unapređenje. Disproporcionalni i sve ubrzaniji porast broja teorijskih struja i stremljenja nikako ne može nadomestiti ovaj nedostatak. Za ocenu stanja nacionalne bezbednosti neke države (manje ili više valjanu), literatura već poznaje

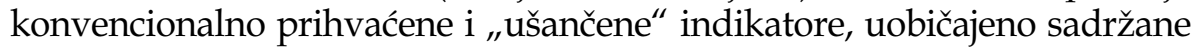
u nacionalnoj legislativi. I podizanje stepena nacionalne bezbednosti država uglavnom je predmet nacionalnih strategija bezbednosti istih. O pouzdanoj i preciznoj oceni stanja bezbednosti "globalnog sela", čini se, teško da se može govoriti budući da je prisutno previše raznovrsnih, međusobno isprepletanih i ko-determinišućih faktora i indikatora, te se ovakve analize ne mogu smatrati naročito racionalnim, niti praktično primenljivim. Usled navedenog, i akademici i praktičari sve češće $u$ fokus svoga interesovanja smeštaju regionalni pristup bezbednosti. $U$ tom smislu, konflikt između 
potrebe za različitim oblicima saradnje među državama neke regije (a usled uzajamne njihove međuzavisnosti) i neretko prisutnih nerešenih istorijskih latentnih ili manifestnih sporova i nesuglasica, predstavlja izazov per se. Ovde bi već valjalo napomenuti da, govoreći u kontekstu regionalne bezbednosti, mora biti uvažena kako unutarregionalna tako i međuregionalna bezbednosna dinamika.

Kada je reč o regionalnoj bezbednosti, izazov, svakako, predstavljaju i ograničene mogućnosti usklađivanja delovanja različitih aktera sa novonastalim promenama u izrazito dinamičnom bezbednosnom okruženju. Navedeno zahteva visok stepen spremnosti svih relevantnih bezbednosnih aktera i naročito razvijenu njihovu koordinaciju (Stanković 2020b, 192). Sa druge strane, jedan od osnovnih uslova za pružanje valjanog odgovora na savremene bezbednosne pretnje jeste, što je potpunije moguće, poznavanje svih relevantnih okolnosti koje bi potencijalno ispoljile efekte značajne za dalji tok bezbednosne dinamike. U uslovima izražene neizvesnosti i nepredvidivosti neophodno je, dakle, obezbediti uslove za kontinuirano praćenje promena u okruženju i pružanje blagovremenog odgovora na iste. Utvrđivanje pouzdanosti ocene rizika i njene osetljivosti na sasvim konkretne uslove i okolnosti, valjano izračunavanje verovatnoće realizacije pretnje, te izračunavanje verovatnoće posledica negativnog događaja, uz uvažavanje postojećeg stepena ranjivosti i kritičnosti, i činjenice da pretnje mogu biti i kombinovane (interne i eksterne), preduslov je za pružanje blagovremenog i adekvatnog odgovora na bezbednosne pretnje. Konačno, čini se da bi i predstavljanje svih relevantnih rizika na integralnoj mapi rizika (Keković i dr. 2009) doprinelo ostvarenju ovako postavljenog cilja.

Imajući $u$ vidu sve prethodno navedeno, $u$ fokusu ovoga rada naći će se koncept rezilijentnosti, utemeljen $\mathrm{u}$ opštoj teoriji sistema, uz uvažavanje potencijala koji bi različite formalne teorije bezbednosti i različiti modeli matematičko-operacionih istraživanja ostvarili u pravcu analize, ocene i unapređenja stanja regionalne bezbednosti. Naime, rezilijentnost, kao jedan od frekventnijih pojmova $u$ terminologiji različitih nauka i naučnih disciplina, a u skorašnje vreme i društvenih i humanističkih, u studijama bezbednosti, naročito na domaćim prostorima, tek je u svom začetku. Rezilijentnost se konceptualizuje na različite načine, zavisno od disciplinarne pozicioniranosti i stručnog profila autora koji se njome bave. Pa ipak, čini se da bi benefiti njene upotrebe, $\mathrm{u}$ izvesnoj meri modifikovane i prilagođene potrebama u sferi bezbednosti, bili brojni. Najpre, rezilijentnost u svojoj kvalitativnoj (deskriptivnoj) formi može poslužiti kao validan konceptualni 
okvir. Dalje, pokušajem njene kvantifikacije (izradom prigodnih indikatora i kreiranjem skale rezilijentnosti) potencijalno bi se mogli postići dvostruki efekti: analiza i ocena stanja bezbednosti nekoga regiona, ali i smanjenja njegove ranjivosti/povećanja otpornosti, odnosno jačanja rezilijentnosti samog regiona na postojeće i potencijalne buduće bezbednosne rizike i krize. Upotreba rezilijentnosti kao metodološkog oruđa bi se mogla postići sintezom relevantnih sadržaja rezilijentnosti preuzetih iz različitih naučnih disciplina, sa uporištem u sistemskoj teoriji, te uvođenjem novih sadržaja karakterističnih za potrebe bezbednosti, tj. proisteklih iz osobenosti savremenih regionalnih bezbednosnih izazova, rizika i pretnji. Konačno, $u$ vidu kritičkog osvrta, u radu će biti dotaknuto i pitanje regionalnog bezbednosnog okruženja Republike Srbije.

\section{RAZVOJ TEORIJSKE MISLI O REGIONALNOJ BEZBEDNOSTI}

Interesovanje teoretičara bezbednosti za regione potiče iz političke geografije, međunarodne ekonomije, međunarodnih odnosa i drugih srodnih naučnih disciplina. U literaturi se začetkom prvih ideja o proučavanju međunarodne politike i međunarodnih odnosa u regionalnom kontekstu smatra period između 50-ih i 70-ih godina XX veka. Prvi rad, $u$ čijem fokusu se nalazila ova problematika, navodi se "Izazov regionalizma" Ernsta B. Hasa (Ernst B. Haas) iz 1958. godine. U obilju različitih, neretko i kontradiktornih teorijskih pristupa regionalnoj bezbednosti, čini se da je $\mathrm{u}$ ovom periodu konsenzus među autorima postojao samo u pogledu činjenice da bi države koje čine određeni region trebalo da imaju značajno više zajedničkih karakteristika sa ostalim državama koje pripadaju istom regionu, a za razliku od onih država koje nisu njegov deo. Govoreći o ključnim karakteristikama koje bi neki geoprostor trebalo da poseduje ne bi li se smatrao regionom, čini se osnovanim ukazati na shvatanje Brusa Raseta (Bruce M. Russet) koji identifikuje pet konkretnih kriterijuma koji moraju biti zadovoljeni (1967, 182). Reč je o sociokulturnoj homogenosti, sličnim političkim stavovima i ponašanju, zajedničkom članstvu u međunarodnim organizacijama, ekonomskoj međuzavisnosti, te geografskoj blizini.

U periodu Hladnog rata i bipolarnog svetskog poretka, većina određenja regiona bila je primarno usmerena na supersile, SAD i/ili SSSR, polazeći od pretpostavke da one vrše krucijalni uticaj na bezbednosnu dinamiku na regionalnom nivou (Russet 1967; Thompson 1973; Feld and Boyd 1980; 
Väyrynen 1984). Osnovna determinanta ovih pristupa oličena je $u$ tome što se regioni posmatraju isključivo iz perspektive supersile, bilo da je reč o mogućnostima kreiranja jedinstvene spoljne politike regiona, kakvog regionalnog institucionalnog povezivanja od značaja za globalni nivo ili drugo. Interesantno je ukazati na shvatanje Vernera Filda (Werner J. Feld) i Gavina Bojda (Gavin Boyd) prema kome supersile i velike sile, kao spoljni akteri, pri kreiranju bezbednosne politike ka određenom regionu moraju uzeti u obzir i mogućnost da im se neke ili sve države zajednički suprotstave, dok se, s druge strane, ističe i da se bezbednosne politike prema konkretnim državama regiona moraju prilagoditi mogućim reakcijama njenih suseda (1980, 3). Raimo Vajrejnen (Raimo Väyrynen) (1984), slično, zaključuje da dominantna struktura globalnog sistema sadrži ili određuje moguće izbore (delovanja) $\mathrm{u}$ regionalnom podsistemu, naročito one koji se nalaze na raspolaganju manjim državama tog regiona. On, dalje, zaključuje da je analiza strukture međunarodne moći i načina na koji se ona koristi od suštinskog značaja, ali da je region, ipak, dinamičan sociopolitički prostor čija dinamika implicira promenu i u sociopolitičkom i u kulturološkom smislu (Väyrynen 1992). Imajući prethodno navedeno u vidu, zaključuje se da je $u$ periodu Hladnog rata pod proučavanjem regiona zapravo podrazumevano proučavanje odnosa između supersila i regiona, odnosno bezbednosne politike supersila prema konkretnim regionima, zapostavljajući time regionalnu bezbednosnu dinamiku u pogledu bezbednosne međuzavisnosti i konfliktnog potencijala samih država na nivou jednog regiona (Lipovac 2016).

Sa krajem Hladnog rata dolazi do intenziviranja regionalne bezbednosne dinamike, odnosno konflikata, kompetencije ili saradnje među državama jednog regiona, lišenih uticaja neke supersile. Pod posthladnoratovskim pojmovnim određenjem regiona podrazumeva se teritorija i/ili akvatorija srednje veličine koja predstavlja podesan okvir za proučavanje bezbednosne međuzavisnosti država (Lipovac 2016, 87). Drukčije rečeno, region obuhvata one države koje imaju veći stepen bezbednosne interakcije međusobno, $\mathrm{u}$ odnosu na države koje nisu deo tog regiona (Lipovac 2016, 87). Konačno, iz bezbednosne perspektive, regionima se smatraju prostori koji obuhvataju države koje uspostavljaju značajne interakcije, a koje presudno utiču na bezbednosnu dinamiku tog regiona.

U središtu novih regionalnih pristupa međunarodnim odnosima i bezbednosti smešten je koncept regionalnosti (regioness). Prema mišljenju Bjor Hetnea (Björn Hettne) i Fredrika Sederbauma (Fredrik Söderbaum), 
upravo ovaj koncept oslikava svu multidimenzionalnost efekata regionalizacije određenog geografskog područja $(2000,458)$. Regionalnost se, dakle, tumači kao kvalitet koji određenom geografskom prostoru daje karakter "regiona“ u suštinskom smislu (Lipovac 2016), odnosno kao koncept samoodređenja nekog regiona $\mathrm{u}$ artikulisanju svog (regionalnog) identiteta i interesa u odnosu na druge aktere, a što, istovremeno, predstavlja osnovu za prepoznavanje regiona kao takvog od strane drugih (Hettne 2005, 556). Govoreći o nastanku regiona, literatura studija bezbednosti poznaje tri pristupa ili načina na koje regioni stiču svoju regionalnost (Nojman 2011, 135-159). Prvi pristup je tzv. pristup „iznutra ka spolja“ (inside-out approach), $\mathrm{u}$ kome se akcenat nalazi na unutrašnjim prirodnim i društvenim specifičnostima poput klime, kulture, jezika, ekonomske povezanosti i šire međuzavisnosti. Suprotno ovome, drugi pristup je tzv. pristup „spolja ka unutra" (outside-in approach) koji primat u objašnjenju nastanka regiona daje spoljnim karakteristikama, kao što su uloge i interesi velikih sila tog regiona, interakcije sa međunarodnim sistemom, prirodne geopolitičke granice i dr. Najzad, treći pristup se odnosi na „izgradnju regiona“ (region building approach), a čiji je predstavnik i sam Iver Nojman (Iver B. Neumann). Prema ovom pristupu, region je socijalno konstruisana kategorija koja nastaje na temelju odnosa moći, identiteta i interesa političkih aktera koji se „prelamaju“ na tom konkretnom regionu (Anderson 1983; Adler 1997; Adler and Barnett 1998; Neumann 1994; Nojman 2011).

$\mathrm{U}$ periodu nakon Drugog svetskog rata dolazi do progresije $\mathrm{u}$ pogledu regionalnog povezivanja i stvaranja regionalne međuzavisnosti u Evropi, a nakon Hladnog rata ova tendencija doživljava i svoj vrhunac. Tako Mark Bison (Mark Beeson) navodi da je ,jedna od najčešće isticanih i kontraintuitivnih karakteristika savremene 'globalne' ere to što ima izrazito regionalni ukus" (regional flavor) $(2005,969)$. Neki teoretičari govore o "višeregionalnom sistemu međunarodnih odnosa" (Hurrell 2007), dokle drugi veruju da već živimo u "svetu regiona“ (Katzenstein 2005). Uprkos činjenici da postoje i oni teoretičari koji umanjuju ili čak u potpunosti isključuju značaj regiona za međunarodnu politiku, regioni nužno utiču na njene različite dimenzije. Naveden stav ilustrativno prikazuje i Amitav Ačarja (Amitav Acharya) tvrdnjom da, premda nisu svi teoretičari međunarodnih odnosa ubeđeni u centralni značaj regiona u međunarodnoj politici, je evidentna regionalna arhitektura međunarodne politike $u$ nastajanju $(2007,630)$. Naposletku, stanovište prema kome regioni imaju 
veliki značaj za oblikovanje međunarodne politike preovladava (Mansfield and Milner 1999; Väyrynen 2003; Hettne 2005).

Kako je već navedeno, regionalni oblici saradnje i povezivanja u sferama ekonomije, politike i odbrane u Evropi su u ovom periodu intenzivirani, i u tom smislu prvenstveno govorimo o Evropskoj uniji - kao međuvladinoj uniji država koje veoma blisko sarađuju u različitim oblastima, a naročito u ekonomiji, spoljnoj politici i bezbednosti, zatim NATO - kao organizaciji država udruženih oko zajedničkih odbrambeno-bezbednosnih ciljeva (okupljajući države kroz punopravno članstvo ili kroz program Partnerstvo za mir), te OEBS-u - regionalnoj međuvladinoj organizaciji koja okuplja države sa zajedničkim ciljevima, prvenstveno u pogledu zaštite i unapređenja ljudskih prava. Ne bi li uspeli adekvatno da odgovore na novonastale promene bezbednosne dinamike, teoretičari razvijaju nove pristupe kao pokušaje da objasne njeno intenziviranje na nivou regiona. Osim prethodno pomenutih, $\mathrm{u}$ ovome periodu značajno interesovanje za regione pokazuju i Dejvid Singer (David J. Singer) (1961), Džozef Naj (Joseph S. Nye) (1968), Luj Kantori (Louis Cantori) i Stiven Spigel (Steven Spiegel) (1970), Ronald Jalem (Ronald Yalem) (1977) i drugi. Značajan je u tom smislu i stav Berija Buzena (Barry Buzan) da je za obuhvatnije proučavanje bezbednosti „srednji nivo analize važan, ali i ozbiljno zapostavljen“, budući da je fokus na analizi bezbednosti na nivou država, kako $u$ vidu analize nacionalne bezbednosti, tako i u vidu analize „kriznih žarišta“ $(1983,105)$. Sa druge strane, prema mišljenju istog autora, mnoga istraživanja su usmerena i na „velike apstrakcije sistemskih analiza, međutim, između njih pronalazimo samo maglovite i izvedene pojmove regionalne ravnoteže snaga i podsistema", pa ipak, „upravo u ovoj središnjoj oblasti, koncept bezbednosti može imati jednu od svojih najkorisnijih primena" (Buzan 1983, 105).

Jasno je, dakle, da su u proučavanju regiona prisutna veoma raznolika teorijska utemeljenja. Iz tog razloga, Valter Matli (Walter Mattli) vrši klasifikaciju ovih teorijskih pravaca deleći ih na one koji nastanak i postojanje regiona objašnjavaju političkim ili ekonomskim pristupom. U političke pristupe svrstava funkcionalizam, neofunkcionalizam i intergovermentalizam, ističući da se oni baziraju na specifičnostima političkog konteksta u kome se odvija proces integracije (Mattli 1999, 19-40). Uprkos tome što su za predstavnike funkcionalističkog i neofunkcionalističkog pravca od najvećeg značaja ciljevi integracionih procesa (očuvanje mira ili podsticanje blagostanja), razmimoilaze se u pogledu aktera koji mogu biti pokretači regionalnog povezivanja. Za prve su to isključivo nadnacionalne institucije, dokle za druge to mogu biti i 
podnacionalni akteri. Nasuprot njima, zastupnici intergovermentalizma smatraju da regionalno povezivanje država pokreću isključivo nosioci izvršne vlasti, i to s ciljem uvećanja moći i bogatstva tih država (Mattli 1999, 19). Sa druge strane, predstavnici ekonomski orijentisanih pristupa uglavnom se fokusiraju na odnose stvaranja zajedničkih tržišta i regulisanje međusobnih ekonomskih odnosa. Kritikom oba ova pristupa Matli, kombinujući uticaj političkih institucija i tržišta, razvija i vlastiti istraživački pristup.

Značajno je istaći još i da, osim unutarregionalne bezbednosne dinamike, postoji i međuregionalna dinamika. Međuregionalna bezbednosna dinamika takođe je bila zapostavljena u periodu Hladnog rata, dok danas predstavlja jedno od značajnijih istraživačkih polja u studijama bezbednosti. Dva najpoznatija teorijska pristupa nastala nakon perioda Hladnog rata, a u kojima se tematizuju i unutarregionalna i međuregionalna bezbednosna dinamika, jesu teorija sukoba civilizacija Semjuela Hantingtona (Samuel $P$. Huntington) (2000) i teorija regionalnog bezbednosnog kompleksa Buzena, a koju su kasnije Buzen i Ule Vejver (Ole Wæver) (2003) zajednički unapredili. Ova dva najuticajnija teorijska stanovišta primarno su razvijena za potrebe proučavanja bezbednosti na regionalnom, odnosno podsistemskom nivou, s tim da, iako dominantno usmereni na regionalni nivo bezbednosti, predstavnici obe ove teorije smatraju da se uspostavljena regionalna bezbednosna dinamika ispoljava i na sistemskom (globalnom) nivou i na nivou jedinica (nacionalnom nivou).

\section{SAVREMENI BEZBEDNOSNI PROBLEMI KAO KOMPLEKSNE PROBLEMSKE SITUACIJE}

\section{Sistemski pristup rešavanju savremenih bezbednosnih problema}

Jedan od ključnih preduslova za razumevanje bezbednosne dinamike savremenog sveta, na sva tri nivoa analize međunarodnih odnosa, jeste kompleksnost. Kompleksnost je svojstvo inherentno svim složenim sistemima, pogotovo onima koji podrazumevaju ljudsku delatnost. Osim činjenice da kompleksni sistemi (poput društva, države, regiona itd.) podrazumevaju postojanje velikog broja autonomnih agenata (elementi sistema) koji međusobno interaguju na najrazličitije načine $u$ pravcu ostvarenja zajedničkog cilja (kao realni, otvoreni, dinamički socijalni sistemi), značajno je istaći i da je sama priroda ove uzajamne povezanosti 
kompleksna, budući da svaki od aktera može posedovati najrazličitije (neretko i konfliktne) interese i ciljeve (Stanković 2021b). Ovo je, naročito, očigledno kada govorimo o unutarregionalnoj i međuregionalnoj bezbednosnoj dinamici, odnosno veoma različitim (često konfliktnim) interesima i ciljevima, kako država jednog regiona tako i regiona sa drugim regionima. Govoreći o regionalnoj bezbednosti ključni akteri bi, dakle, bili regioni po sebi, države, različite nadnacionalne organizacije, te supersile ili velike sile od uticaja na određeni region.

Pa ipak, u kontekstu ovoga rada, značajnom se čini i činjenica da ni okruženje sistema nije statički entitet, već povratno deluje na svakog od aktera dinamički i raznovrsno (Stanković 2021b). Ovde govorimo o međuregionalnoj dinamici, u smislu uticaja koje okruženje tog regiona (supersile ili drugi regioni) vrši na određeni region. Takođe, premda se ne nalazi u fokusu ovoga rada, pod uticajem okruženja možemo podrazumevati uticaj regionalnog okruženja na neku državu. Posledično, u kompleksnim sistemima nema determinisanosti već je na delu neizvesnost. Radi razumevanja kompleksnih sistema, osim razumevanja agenata ponaosob, potrebno je razumeti i sve vidove i varijacije interakcija među njima, uključujući i interakcije proistekle iz okruženja, odnosno sa okruženjem. Stoga, "okvir za rešavanje kompleksnosti zavisi od novih osobina dobijenih iz sinergije interacije međusobno zavisnih delova“ (Petrović 2006, 39).

Govoreći o savremenim bezbednosnim izazovima, rizicima i pretnjama kao bezbednosnim problemima, uobičajeno je reč o nedovoljno struktuiranim problemima koje prate različite neodređenosti. Najčešće je prisutno otežano prepoznavanje svih elemenata (npr. svih relevantnih aktera od uticaja), njihovih međusobnih interakcija, među sobom i sa okruženjem (od kojih su mnoge latentne i „prikrivene“), te potencijalnih mnogobrojnih ishoda. Budući da ishodi po svojoj suštini predstavljaju rezultat delovanja brojnih i različitih faktora (kako objektivnih tako i subjektivnih), u odnosu na aktere i okruženje, koji se, čak i kada su prepoznati, ne mogu uvek adekvatno i kvantifikovati, jedna od najvećih prepreka u suočavanju sa ovakvim problemima jeste činjenica da se problem može samo fragmentarno (ukoliko uopšte i može) definisati, odnosno njegovo rešavanje formalizovati (Stanković 2021b). Dodatno, premda se u rešavanju bezbednosnih problema načelno govori o jednom primarnom cilju (rešenju toga problema), njegova optimizacija nužno podrazumeva da realizacija ostalih, pojedinačnih ciljeva biva delimično ili u potpunosti 
osujećena. Drukčije rečeno, uzajamna zavisnost delovanja različitih agenata čini da delovanje jednog od njih neminovno utiče i na ostale. $U$ tom smislu se govori o postojanju mnoštva različitih rešenja problemske situacije, odnosno različitih načina za postizanje konačnog cilja, a koji mogu imati različite svrhe, u skladu sa prioritizacijom pojedinačnih (Stanković 2021b).

Budući da savremeni bezbednosni izazovi, rizici i pretnje uobičajeno prevazilaze okvire jedne sfere društvenog života, dovodeći do dramatičnih posledica i u drugima, odgovoru na njih ne pogoduje redukcionistički pristup. Razlog navedenom ogleda se u činjenici da se prostim deljenjem na izolovane probleme (prema oblastima) ne može dobiti rešenje koje bi se, naknadnom sintezom, moglo primeniti na širi nivo (Stanković 2021b). Kao primer može poslužiti gotovo bilo koji od savremenih bezbednosnih izazova, poput terorizma, verskog i etničkog ekstremizma, separatizma i radikalizma, korupcije, organizovanog kriminala i sl., čiji uticaji dovode do posledica u skoro svim sferama društvenog života. Iz tog razloga, govorimo o kompleksnoj problemskoj situaciji koja predstavlja svojevrsnu „šemu zajedničke interakcije i višestruke kauzalnosti“, kao i ko-determinisanosti. Pritom, mora se imati na umu i činjenica da priroda ove šeme neretko deluje nejasno (Petrović 2006). Kompleksne probleme, kako je već istaknuto, karakteriše veliki broj interakcija velikog broja subjektivnih i objektivnih faktora različitih prema tipu, kao i prema prioritetnosti, veliki broj različitih aktera sa različitim ciljevima i (neretko i kontradiktornim) interesima, koji se "umrežavaju“ da bi se došlo do odabira među potencijalnim alternativnim ishodima, a koji bi svima kompromisno odgovarao (Stanković 2021b). Dokle su na nacionalnom nivou svi pojedinačni interesi i ciljevi barem načelno usklađeni sa opšteprihvaćenim definisanim nacionalnim interesima, u slučaju regiona nacionalni interesi određenih država mogu biti i u potpunoj suprotnosti, čime se „potraga“ za jedinstvenim rešenjem koje bi kompromisno odgovaralo obema stranama neretko čini gotovo nemogućom.

Nužan preduslov upravljanja ovakvom kompleksnošću predstavlja kreiranje organizovanog okvira koji bi obuhvatao sve elemente sistema agente, interese, ciljeve, aktivnosti i mere, resurse, te, naposletku, i alternativne ishode (Stanković 2021b). Nemogućnost precizne ili, uopšte, valjane deskripcije savremenih bezbednosnih pojava, kao problemskih situacija, dovodi do urgentne potrebe da se $u$ njenom upravljanju koristi dovoljno fleksibilan metodološki instrumentarijum, odnosno na odgovorajući način prilagođen dostignutom stepenu ove kompleksnosti. Naposletku, postoje osnovi i za stav da bi se savremeni bezbednosni fenomeni mogli (i trebalo) 
naći kao predmet matematičko-operacionih istraživanja. Prevazilaženjem "nametnute“ podele na metodologiju prirodnih i društvenih nauka, te uvažavajući prednosti multidisciplinarnog i interdisciplinarnog pristupa rešavanju kompleksnih problema, sistemski pristup se pojavljuje kao najoptimalniji pristup rešavanju savremenih bezbednosnih problema. Čini se, da bi upravo utemeljenje u opštoj teoriji sistema predstavljalo dobru polaznu osnovu za sveobuhvatno, sistemsko sagledavanje, odnosno definisanje ovih kompleksnih problemskih situacija, naročito ukoliko u vidu imamo brojni "alat" kojim raspolaže (prevashodno onaj nastao kao proizvod ubrzanog tehnološkog progresa) (Stanković 2021b).

Govoreći o kompleksnosti njen neizostavni pratilac jeste i neizvesnost. Brojnost i raznovrsnost subjektivnih i objektivnih faktora, aktera, njihovih interakcija i dr., utiču na bezbednosnu dinamiku na način da savremenu bezbednosnu realnost evidentno i nužno karakteriše visok stepen neizvesnosti. Kao posledica navedenog, u praksi su izuzetno retki slučajevi kakvih dugoročnih implikacija bezbednosne dinamike (prevashodno iz razloga njihove nepouzdanosti), dokle je fokus uobičajeno (ili čak isključivo) na kratkoročnim prognozama i predikcijama. Nelinearnost, kao odlika sistema koja onemogućava da se on analizira sa aspekta redukcionizma, dodatno naglašava potrebu za uvažavanjem sistemskog pristupa pri rešavanju savremenih bezbednosnih problema (Stanković 2021b). U tom smislu, neizvesnost predstavlja direktnu posledicu nelinearnosti, jer bi $u$ suprotnom (kada bi se poštovao princip linearnosti) budućnost bila u izvesnom smislu proporcionalna početnom stanju (očekivana i predvidiva), a što svakako nije slučaj. Kada je reč o nelinearnim sistemima, poput društva, države ili regiona, kao uslov se nameće potreba da dovoljno "dobro“ poznajemo i precizno definišemo sve relevantne aspekte trenutnog stanja društva, države, regiona (ili već odabranog sistema) kao sistema (Stanković 2021b). Budući da navedeno iz mnogobrojnih razloga u praksi nije sprovodivo, pri analiziranju bezbednosnih pojava uvek se govori o „više puteva u budućnost“" (Potkonjak-Lukić i Stojanović 2016, 103).

Kako je već prethodno istaknuto, prepoznavanje, a naročito kvantifikacija svih relevantnih (subjektivnih i objektivnih) elemenata sistema (varijabilnosti karakteristika i interakcija društva itd.), nije uvek moguća, te se stoga, kao jedino merodavno, uvek valja opredeliti za utvrđivanje čitavog raspona puteva u budućnost, a što se u teoriji naziva "raspon neizvesnosti“ (Saperstein 1997). Čini se neophodnim naglasiti i da se pri svakom predviđanju mora ostaviti "prostora“ nižem ili višem stepenu neizvesnosti. 
Dakle, imajući u vidu izraženu kompleksnost čitavog spleta interakcija koje karakterišu društvo, državu ili region, te činjenicu da je reč o realnim dinamičkim sistemima uvek otvorenim za uticaje iz okruženja (istovremeno i sama povratno utičući na njega), kontinuirana promena je uvek i svuda prisutan proces (Stanković 2021b). Na osnovu navedenog, jasno je da je mogućnost bilo kakvog preciznijeg predviđanja bezbednosnih pojava (pogotovo onih regionalnog i globalnog domena) značajno ograničena njihovom kompleksnošću i nelinearnošću.

Brzina reagovanja ima naročiti značaj kada je reč o savremenim bezbednosnim izazovima, rizicima i pretnjama, budući da ne postoji dovoljno vremena ni da se na valjan način i u potpunosti sagleda i shvati neka novonastala bezbednosna situacija. Svaka, čak i minimalna, izmena poseduje potencijal da vrlo brzo dostigne enormne razmere, s obzirom na to da se "rast greške odvija eksponencijalno (Potkonjak-Lukić i Stojanović 2016, 111). Na taj način, u zavisnosti od načina upravljanja kompleksnošću i nelinearnošću, zavisi da li će društvo, država ili region krenuti put adaptacije i progresa, ili će pak u njima doći do neželjenih i bespotrebnih ljudskih i materijalnih gubitaka, bespotrebnog trošenja resursa, i svih propratnih neželjenih efekata (Stanković 2021b). Naposletku, sistemski pristup je istovremeno i "matematička i intinuitivna“ (Simonović 2011, XXVIII) paradigma. Nažalost, metode i tehnike koji su u upotrebi uobičajeno ne prate dinamiku bezbednosnih pojava i procesa, okruženja, kao ni aktuelnog, vrtoglavog tehnološkog progresa. Uvažavajući potrebu za fleksibilnom i inovativnom metodologijom, primerenoj aktuelnim okolnostima i dostignutom tehnološkom napretku, čini se plodonosnim maksimalno iskorišćavanje potencijala koji nudi primena različitih matematičko-operacionih modela (Stanković 2021b).

\section{Potencijal formalnih teorija bezbednosti za rešavanje savremenih bezbednosnih problema}

Kao posledica izražene kompleksnosti i nelinearnosti, kako društava, država i regiona tako i dinamičnog okruženja, savremeno bezbednosno okruženje determiniše zabrinjavajuće visok stepen neizvesnosti i nepredvidivosti. Ono je opterećeno bezbednosnim izazovima, rizicima i pretnjama različitih izvora i prirode. Rastući „haotični potencijal“ modernih kriza dovodi do urgentne potrebe za preispitivanjem tradicionalnih postulata bezbednosti, a naročito do potrebe za iznalaženjem adekvatnog 
metodološkog instrumentarijuma za razumevanje savremenih bezbednosnih fenomena (Stanković 2020a, 28). Iz tog razloga, potrebno je identifikovati teorijske pristupe koji bi potencijalno bili od značaja za suočavanje sa savremenim bezbednosnim izazovima, rizicima i pretnjama. U uslovima izražene kompleksnosti i neizvesnosti neophodno je kontinuirano i vrlo pažljivo pratiti dinamiku okruženja kako bi se blagovremeno uočile one promene koje mogu biti indikatori ispoljavanja određene bezbednosne pretnje (ovde, ponovo, o okruženju govorimo i u kontekstu unutarregionalne i međuregionalne bezbednosne dinamike). $\mathrm{Za}$ uočenim ranim signalima mora slediti kreiranje svih relevantnih mogućih scenarija ne bi li se efekti nepredvidivosti mogli svesti na najmanju moguću meru, odnosno ne bi li se moglo pristupiti valjanom planiranju odgovora na očekivane bezbednosne pretnje. Blagovremena identifikacija i adekvatna procena rizika predstavljaju nužan preduslov uspeha rešavanja svih savremenih bezbednosnih problema (Stanković 2020a, 37).

Imajući sve navedeno $\mathrm{u}$ vidu, može se sugerisati primena teorije determinističkog haosa, ${ }^{2}$ barem kao alata za rano upozorenje i time izbegavanje strateških iznenađenja. Na taj način bi se mogao prepoznati preteći "haotični“ potencijal bezbednosnih rizika koji se naziru. Predikcija, stoga, može imati dvostruku ulogu u suočavanju sa bezbednosnim izazovima, rizicima i pretnjama. Najpre, prediktivni modeli mogu poslužiti kao referentni okvir za detaljnu analizu i praćenje dinamike i uopšte promena u okruženju, a kako bi se blagovremeno prepoznali i identifikovali faktori rizika koji sistem (društvo, državu ili region) mogu dovesti do značajne nestabilnosti, kolapsa nekih njegovih vitalnih funkcija, ili čak njegove dezintegracije (Stanković 2020a, 38). Sa druge strane, prediktivni modeli, kao deo aparature određenih verzija teorija igara, ${ }^{3}$ mogu doprineti optimalnijem

\footnotetext{
${ }^{2}$ Teorija determinističkog haosa bavi se „kvalitativnim izučavanjem nestabilnog aperiodičnog ponašanja u determinističkim nelinearnim dinamičkim sistemima“ (Kellert $1993,5)$. Uprkos evidentnoj neizvesnosti, upotrebom teorije determinističkog haosa može se predvideti da li će sistem u određenim okolnostima ispoljiti „haotično ponašanje“ (Stanković 2020a, 29).

${ }^{3}$ Cilj primene teorije igara u ovom kontekstu predstavljao bi utvrđivanje određenih „pravila igre“ na osnovu kojih će „igrač“, donošenjem odluka, nastojati da ostvari željeni cilj. Svaki donosilac odluke, osim što mora uzimati u obzir i ciljeve ostalih aktera, mora voditi računa i o njihovim mogućim odlukama, potezima ili strategijama. Na osnovu ovakve "kalkulacije“, akteri donose takve odluke koje za krajnji cilj imaju zadovoljenje, u što je moguće većoj meri, vlastitih interesa, pa čak i ukoliko to „zahteva određeno 'žrtvovanje' u
} 
donošenju odluka, u smislu odlučivanja koje bi u datoj situaciji maksimiziralo "korisnost" ishoda akcija samih aktera (prevashodno spram "prirode“), odnosno minimizirale negativne efekte neizbežnih neželjenih posledica (Stanković 2020a, 38). Konačno, mora se uvažiti i ogroman potencijal koji nosi primena različitih multivarijacionih tehnika ${ }^{4}$ za donošenje što je valjanijih odluka u odgovoru na savremene bezbednosne izazove, rizike i pretnje.

Dakle, sugeriše se da bi primena različitih metoda matematičkooperacionih istraživanja rezultirala potencijalno novim i značajnim uvidima $\mathrm{u}$ ovu problematiku. $\mathrm{U}$ te svrhe, smatramo plodotvornim primenjivanje principa različitih formalnih teorija bezbednosti (Janev 2011), a naročito teorije determinističkog haosa, multivarijacione teorije (na osnovi različitih multivarijacionih analiza), primenjene teorije verovatnoće, teorije katastrofe, pa čak i teorije igara. Govoreći o ovako postavljenom metodološkom okviru, bez obzira na izbor konkretnih tehnika, potrebno je ukazati i na benefite uvažavanja osnovnih postulata pomenute tzv. "rasplinute“ logike (fuzzy logic), a koji bi olakšali rešavanje savremenih bezbednosnih problema sa kojima je "naizgled teško nositi se na racionalan i razuman način“ (Roberts 2017). Osim praktične korisnosti u programiranju i matematičkom modeliranju (veštačkoj inteligenciji uopšte), ovakav pristup pogodan je za operisanje $\mathrm{u}$ okvirima svih prethodno navedenih formalnih teorija bezbednosti, čineći mogućim rešavanje problema šireći spektar mogućnosti u okvirima jasno određenih granica, $\mathrm{i}$ to na osnovu prilično jednostavnih algoritama (Stanković 2020a, 29). „Rasplinuta“ logika, dakle, potencijalno može doprineti redukovanju, u meri u kojoj je to moguće, kompleksnosti, a time i posledične neizvesnosti.

\section{REZILIJENTNOST}

Kao pojam koji ulazi u sve širu upotrebu u različitim naukama i naučnim disciplinama, zauzimajući, pritom, sve značajnije mesto i na polju

određenoj fazi igre, ili odstupanje od maksimalističkih zahteva, uključujući i situacije obostranog dobitka (win-win ili ravnoteže), ili minimalnog gubitka, ako je razvoj situacije nepovoljan" (Kapor 2017).

${ }^{4}$ Multivarijacione tehnike se koriste za simultanu analizu međusobnog odnosa velikog broja varijabli na bazi određenog modela na kojem se zasniva konkretna tehnika, te predstavljaju naročito plodonosan alat za otkrivanje zakonitosti u odnosima varijabli koje su skrivene ili jedva primetne (Stanković 2020a, 31). 
društveno-humanističkih nauka, rezilijentnost se u literaturi konceptualizuje na različite načine. Među pojmovnim određenjima, u zavisnosti od teorijske pripadnosti, ali i konkretnih praktičnih potreba samih autora, najčešće se navode sledeća - sposobnost lakog oporavka od stresa, prilagođavanje stresnim okolnostima, izostanak maladaptivnih reakcija uprkos snažnim negativnim događajima i adekvatno funkcionisanje tokom stresnih događaja (Carver 1998); kapacitet dinamičkog sistema da se uspešno prilagodi pretnjama po njegovo funkcionisanje, život i razvoj, odnosno sposobnost ljudi da "izbegnu“ negativne efekte stresnih i potencijalno oštećujućih događaja, uspešno se vrate na prethodni nivo funkcionisanja ili čak ostvare određeni rast i napredak (Masten 2014); ali i njena primena kao istraživačkog dizajna orijentisanog na varijable, pri čemu se, koristeći različite multivarijacione analize, povezuju mere visokog stepena rizika od negativnog događaja, ishod i potencijalni kvaliteti individua ili situacija koje mogu delovati tako da ublaže ili zaštite osobu od negativnih posledica tih traumatskih događaja (Luthar et al. 2000).

Iz perspektive bavljenja regionima kao kompleksnim sistemima, te kroz prizmu sistemske teorije, najprikladnije je ono određenje rezilijentnosti prema kome je reč o osobini kompleksnih sistema i njihovih elemenata da predvide, apsorbuju i povrate se od poremećaja i, po mogućnosti, poprave osnovnu strukturu sistema i njegovu funkcionalnost (Stanković 2020a, 35). Literatura poznaje nekoliko modela rezilijentnosti od kojih svaki poseduje potencijal za analiziranje uticaja određenih aspekata savremenih regionalnih bezbednosnih izazova, rizika i pretnji. Na ovom mestu bi valjalo istaći i da se pod protektivnim faktorima prevashodno misli na one faktore koji ublažavaju negativan ishod rizik faktora ili promovišu pozitivnu adaptaciju, a čija je značajna karakteristika da deluju isključivo ili jače u stresnim (kriznim) situacijama, dokle je njihov uticaj mimo ovih situacija zanemarljiv ili slabiji (Wolraich et al. 2007). U konkretnom slučaju, pod protektivnim merama mogle bi se, primera radi, smatrati odluke i delovanja određenih nadnacionalnih/regionalnih organizacija i institucija u uslovima izražene nestabilnosti ili već ispoljene konkretne bezbednosne pretnje na nivou regiona. Sa druge strane, pod promotivnim faktorima se misli na one koji deluju i nezavisno od kriznih situacija (Wolraich et al. 2007), te neće u potpunosti anulirati odnos rizik faktora i krajnjeg ishoda već će samo doprineti što kvalitetnijoj adaptaciji. U tom smislu, možemo govoriti o različitim vidovima i merama pomoći i/ili podrške (država, regionalnih organizacija i sl.) koje se sprovode i u uslovima tzv. "normalnog“ 
funkcionisanja u okvirima određenog regiona, ali i o njihovim kapacitetima i resursima, znanju, sposobnostima i veštinama konkretnih aktera i sl.

Komparativni model rezilijentnosti podrazumeva da promotivni faktor deluje u suprotnom smeru od rizik faktora, dokle protektivni faktor ima direktan uticaj na ishod, i taj je uticaj nezavistan od uticaja rizik faktora (Fergus and Zimmerman 2005). Primenjeno na konkretnu problematiku, može se analizirati uticaj, primera radi, nacionalnih legislativa u rešavanju sasvim konkretnih bezbednosnih problema. Protektivni model pak podrazumeva delovanje određenih snaga ili resursa koji utiču na odnos rizičnih situacija i negativnih ishoda i menjaju, tj. smanjuju povezanost rizične situacije i negativnog ishoda (Wolraich et al. 2007). Primenom ovog pristupa može se ispitivati uticaj najrazličitijih vidova pomoći ugroženim državama ili regionima, u bilo kojoj sferi društvenog života, ali i u odnosu na rizike koji ih ugrožavaju. Pomenuti protektivni model rezilijentnosti uobičajeno se deli na dva tipa - protektivno-stabilizirajući i protektivnoreaktivni model (Luthar et al. 2000), u zavisnosti od načina na koje protektivni faktori ostvaruju uticaj na povezanost rizičnog događaja i krizne situacije. Prvi je primenljiv na situacije u kojima protektivni faktor doprinosi neutralizaciji uticaja rizičnog događaja, pri čemu su viši nivoi rizika povezani sa značajnijim negativnim ishodom ukoliko protektivni faktor izostane, odnosno ukoliko on postoji ne očekuje se povezanost rizične situacije i konačnog ishoda (Fergus and Zimmerman 2005). Sa druge strane, protektivno-reaktivni model primenjuje se na situacije u kojima protektivni faktor smanjuje, ali ne uklanja u potpunosti očekivanu povezanost rizik faktora i negativnog ishoda, odnosno u kojima je povezanost rizik faktora i negativnog ishoda jača ukoliko protektivni faktor izostane.

Veoma je interesantan $u$ kontekstu problematike ovoga rada i model izazova. Reč je o modelu kojim se potencijalno može objasniti nelinearna, zakrivljena veza rizik faktora i ishoda, pri čemu se sugeriše da sama izloženost rizičnim situacijama (iskustvima) može imati protektivnu ulogu, odnosno kojim se sugeriše da je izloženost niskim i visokim nivoima rizika povezana sa negativnim ishodom, dokle su umereni nivoi rizika povezani sa manje negativnim (ili čak pozitivnim) ishodima (Fergus and Zimmerman 2005). Ovaj model obuhvata i model inokulacije, odnosno pretpostavku da će upravo kontinuirana ili ponavljana izloženost rizik faktorima doprineti tome da se pojedinac, društvo, država ili region u budućnosti adekvatnije nose sa rizicima i lakše ih prevaziđu (Stanković 2020a, 37). Kao primer kontinuirane izloženosti nekom rizik faktoru možemo navesti one države 
nekog regiona, pa i čitave regione, koji su već decenijama ili čak vekovima, "opterećene" određenim bezbednosnim problemima, te su, u izvesnom smislu, "naviknute“ na takvu bezbednosnu dinamiku, odnosno ne smatraju rešavanje ovih pitanja prioritetnim. Kao primer ponavljane izloženosti određenom rizik faktoru koja doprinosi boljem upravljanju ovim rizicima u nekom budućem trenutku mogu poslužiti države i/ili regioni kojima je pređašnje iskustvo suočavanja sa nekim bezbednosnim rizicima i pretnjama donelo "pouke“ (naučene lekcije) koje im omogućavaju da ih u budućnosti dočekaju spremniji i sa njima se lakše nose.

\section{Rezilijentnost $u$ studijama bezbednosti}

Koncept rezilijentnosti, poreklom primarno iz tehničkih nauka, u nauku o bezbednosti se uvodi kao „potencijalno rešenje i odgovor na neizvesnost koju donosi veliki broj rizika i asimetričnih pretnji“" (Keković i Dinić 2016, 1142). Transformisana priroda savremenih bezbednosnih izazova, rizika i pretnji dovodi do potrebe za jačanjem kapaciteta i sposobnosti svih aktera (na nacionalnom, regionalnom ili globalnom nivou) da na adekvatan način odgovore na njih, te da se u najkraćem roku oporave, uz što je moguće manje posledice. Prevencija i spremnost (readiness) predstavljaju ključne komponente rezilijentnih sistema, nužan uslov za adekvatan odgovor na ispoljene pretnje i sposobnost za brz oporavak, „uz očuvanje suštinskog identiteta i vitalnih vrednosti sistema" (UNDRR 2008, 3). Rezilijentnim se, dakle, može smatrati onaj sistem (društvo, država, region ili dr.) koji je sposoban da nastavi svoje funkcionisanje bez remećenja suštinskih funkcija, da amortizuje neželjene uticaje, te da se brzo „regeneriše" (Keković i Dinić 2016, 1143).

U studijama bezbednosti, termin „rezilijentnost" se uobičajeno koristi kao atribut kome bi države (dodajemo - i regioni) trebalo da teže, i to uglavnom nakon već ispoljenih bezbednosnih pretnji. Različita terminološka određenja rezilijentnosti pojavljuju se kako u literaturi tako i strateškim i drugim zvaničnim dokumentima država, pri čemu najrelevantnijim smatramo sledeća - „kapacitet sistema da apsorbuje poremećaje, podvrgne se promenama i zadrži iste osnovne funkcije, strukturu, identitet i povratne informacije" (Longstaff et al. 2010); "sposobnost sistema, infrastrukture, vlade, poslovanja i građana da se odupru, apsorbuju, oporave ili prilagode negativnim pojavama koje mogu prouzrokovati štetu, uništenje ili gubitak od nacionalnog značaja“ (Risk Steering Committee 2008); "sposobnost 
organizacije da prepozna pretnje i opasnosti i izvrši adaptaciju koja će poboljštati buduće napore u zaštiti i mere za smanjenje rizika“" (Risk Steering Committee 2008); „,sposobnost smanjenja veličine i/ili trajanja ometajućih događaja“, pri čemu „rezilijentnost kritične infrastrukture ili preduzeća zavisi od njegove sposobnosti da predvidi, apsorbuje, adaptira se i/ili brzo oporavi od potencijalno ometajućeg događaja" (National Infrastructure Advisory Council 2009); „sposobnost adaptacije promenljivim uslovima i pripreme da izdrže i brzo se oporave od poremećaja" (NSS USA 2010); te "robustnost, adaptibilnost i sposobnost brzog oporavka“ (US Department of Defense 2010).

Etimološki posmatrano, termin „rezilijentnost“ izveden je iz latinskog glagola resilire, u značenju "skočiti unazad“, što je u skladu i sa starijim tumačenjima ovog koncepta kao svojstva sistema da se „odbije nazad u stanje ravnoteže pre poremećaja", a što je posledica sposobnosti da apsorbuje šokove iz okoline i održava svoju funkciju (Keković i Ninković 2020, 154). Protekom vremena, koncept rezilijentnosti je „proširen“ u smislu da uključuje i sposobnost sistema da se suoči sa promenama, te da im se prilagodi (Fraccascia et al. 2018). Konačno, u najnovijoj literaturi se ovaj koncept "obogaćuje" i sposobnošću da ne samo da se povrati u prethodno stanje (stanje uobičajenog funkcionisanja), već i da se unapredi i progresira (poznata strategija “build back better"). Pa ipak, povezujuća „nit“ raznolikih tumačenja koncepta rezilijentnosti ogleda se u uvažavanju kompleksnosti, nelinearnosti, nepredvidivosti, te samo-organizacije. Konačno, rezilijentnost pruža složenim sistemima sposobnost da izdrže i prežive šokove i poremećaje, te naglašava sposobnost obnavljanja (Keković i Ninković 2020, 155).

Kao što je već prethodno istaknuto, jedna od ključnih prepreka valjanom odgovoru na savremene bezbednosne pretnje jeste nemogućnost (ili, preciznije, nesposobnost) da se one predvide, identifikuju i na njih blagovremeno reaguje. $U$ tom smislu, govorimo o tri kapaciteta rezilijentnosti - apsorptivnom, adaptivnom i restorativnom, uz uvažavanje činjenice da neki autori ovome dodaju i četvrti kapacitet, prediktivni (Keković i dr. 2014). Apsorptivni kapacitet se odnosi na stepen do kog sistem može automatski da apsorbuje uticaj sistemskih poremećaja i umanji posledice uz malo napora, adaptivni kapacitet se odnosi na stepen u kojem je sistem sposoban za samoorganizaciju za oporavak nivoa performansi sistema i, konačno, restorativni kapacitet predstavlja sposobnost sistema da se lako popravi (bilo u prvobitno stanje pre kritičnog događaja ili u potpuno novo stanje koje predviđa buduće zahteve sistema) (Keković i dr. 2014). 
Interesantnim se, $\mathrm{u}$ kontekstu aktuelne bezbednosne dinamike, čini adaptivni kapacitet rezilijentnosti, budući da se ona tumači kao emergentno svojstvo kompleksnih adaptivnih sistema (Barasa et al. 2018). Adaptacija u tom smislu pretpostavlja postojanje otvorenijeg sistema koji bi trebalo prilagoditi ili dovesti u ravnotežu od strane socijalnih agenata (aktera). Rezilijentnost kroz adaptaciju nastaje odlukama da se napusti „put“ koji se u prošlosti možda pokazao uspešnim u korist nove (srodne ili alternativne) putanje (Keković i Ninković 2020, 155). Stoga se upravo ovaj adaptivni kapacitet rezilijentnosti čini neophodnim za suočavanje sa nepredvidivim savremenim bezbednosnim izazovima, rizicima i pretnjama. Adaptivni kapacitet je, dakle, ,, dinamički kapacitet da se izvrši i razvije više evolucionih putanja kroz 'labave' veze koje postoje između socijalnih agenata, što povećava ukupnu reaktivnost sistema na nepredviđene promene“ (Pike et al. 2010).

\section{Regionalno bezbednosno okruženje Republike Srbije - bezbednosni izazovi, rizici i pretnje}

U Strategiji nacionalne bezbednosti Republike Srbije iz 2019. godine, analizom bezbednosnog okruženja na globalnom, regionalnom i nacionalnom nivou, identifikovani su ključni bezbednosni izazovi, rizici i pretnje Republici Srbiji, a potom i definisani nacionalni interesi i konkretni ciljevi čijim bi se ostvarenjem obezbedila zaštita proklamovanih nacionalnih interesa. Na osnovu navedenog, značaj valjano izvedenih zaključaka o bezbednosnom okruženju Republike Srbije je neosporan. Drugim rečima, očigledno je da će od toga koji se faktori iz okruženja naglašavaju ili pak zanemaruju, zavisiti i koji se izazovi, rizici i pretnje prepoznaju kao prioritetni. Nepostojanjem konsenzusa među ekspertima $u$ pogledu preciznih i jasnih kriterijuma analize bezbednosnog okruženja, a imajući u vidu činjenicu da se ni u samoj Strategiji ne prikazuju primenjeni indikatori, ostaje otvorena mogućnost da je dobijena ocena o bezbednosnom okruženju proizvod percepcije onih koji su u njenoj izradi učestvovali, ali i aktuelnog političkog ambijenta u zemlji (Stanković 2021a, 84). S tim u vezi, ostaje otvoreno pitanje zašto u novoj Strategiji nacionalne bezbednosti iz 2019. godine, a za razliku od prethodne iz 2009. godine, izlaganje nije strukturisano $\mathrm{u}$ odnosu na tri nivoa analize - globalno, regionalno i „nacionalno“ okruženje. Premda u sadržaju aktuelne Strategije nema značajnijih odstupanja u odnosu na prethodnu (barem u okvirima ovog 
segmenta, ili barem razlika koje bi opravdale ovakav izbor), smatramo da je, iz praktičnih i drugih razloga, bolje rešenje predstavljala struktura ovog poglavlja sadržana u Strategiji nacionalne bezbednosti iz 2009. godine (Stanković 2021a, 85).

Kako je već istaknuto, analizirajući aktuelnu Strategiju nacionalne bezbednosti, kao referentni okvir za analizu regionalnog bezbednosnog okruženja Republike Srbije, prvi utisak koji se stiče jeste da nema značajnijih izmena u odnosu na sadržaj prethodne Strategije. Naime, postojeći načelni stavovi eventualno su dodatno razjašnjeni ili dopunjeni. Dakle, osim pretnji identifikovanih na globalnom nivou, a koje se potom ponavljaju i u kontekstu regionalnog bezbednosnog okruženja, kao izazovi, rizici i pretnje postojane i u aktuelnoj Strategiji (2019) ostaju nasleđeni problemi iz prošlosti, istorijske protivrečnosti, posledice suprotstavljanja naroda i država na prostoru jugoistočne Evrope, naročito Balkana, geostrategijski položaj u vezi sa korišćenjem tranzitnih pravaca, jednostrano proglašena nezavisnost Kosova i Metohije, neadekvatno rešavanje povratka izbeglih, prognanih i interno raseljenih lica, uništavanje kulturnog nasleđa, te nedovoljna izgrađenost državnih institucija. Dva krucijalna pitanja jesu pitanje Kosova i Metohije i integracije u Evropsku uniju. U aktuelnoj Strategiji nacionalne bezbednosti naglašeno je da integraciju država koje teže članstvu u Evropskoj uniji mogu usporavati nerešeni institucionalni i ekonomski problemi, nespremnost za sprovođenje neophodnih reformi i usklađivanje sa pravom ove organizacije, bilateralni sporovi koji su izgovor za usporavanje procesa evropskih integracija, kao i problem nestalih lica, nadležnosti u procesuiranju ratnih zločina, nesprovođenje Briselskog sporazuma, sporo uspostavljanje demokratskog standarda na Kosovu i Metohiji, nepoštovanje osnovnih prava srpskog i drugog ne-albanskog stanovništva, uzurpacija i uništavanje njihove imovine i kulturno-istorijske baštine, te jačanje radikalnog islamizma. Takođe, naglašavaju se i negativni uticaji pokušaja revizije Dejtonskog sporazuma, ali i težnja i pokušaji u pojedinim državama da se ostvari što veći stepen nacionalnog ujedinjenja etničkog prostora i realizacije velikodržavnih projekata (posebno stvaranje Velike Albanije), a koji bi uključivali „reviziju i promenu međunarodnopravno utvrđenih državnih granica i ovlašćenja“ (Strategija RS 2019).

Interesantan je i način na koji se u Strategiji nacionalne bezbednosti govori o ekonomskom aspektu regionalne bezbednosti, u smislu naglašavanja „spoljnih" uzroka nezadovoljavajućeg stanja, „uprkos pozitivnim efektima mera koje preduzimaju gotovo sve vlade“ , i nastojanja država regiona "da 
smanje javni dug i nezaposlenost realizacijom strateških projekata koji se realizuju u okviru procesa evropske integracije i Berlinskog procesa" (Strategija RS 2019). Stiče se utisak da je glavni „krivac“ ili ključni faktor ugrožavanja u tom smislu globalno tržište, odnosno globalna ekonomska kriza „"koja se prelila sa povezanih tržišta i ekonomija“ (Stanković 2021a, 87). Najzad, ocenjeno je da rizici od izbijanja ratova i drugih oružanih sukoba na prostoru jugoistočne Evrope, iako smanjeni, nisu i eliminisani, pri čemu se zaključuje da na situaciju u regionu trenutno najveći uticaj imaju pitanje statusa Autonomne Pokrajine Kosovo i Metohija, međuetničke tenzije, kao i migrantska kriza. U vezi sa regionalnim inicijativama i zajediničkim naporima država regiona za suzbijanje negativnih procesa i pojava, odnosno izgradnju zajedničkih mehanizama za prevenciju rizika i pretnji, polazi se od "zajedničkog interesa država regiona da pristupe Evropskoj uniji“ (Strategija RS 2019). Kako je već više puta istaknuto, kao glavni izvor nestabilnosti u Republici Srbiji i regionu izdvajaju se problemi na prostoru Autonomne Pokrajine Kosovo i Metohija, a s tim u vezi i „moguća uslovljavanja u procesu pristupanja Evropskoj uniji koja se odnose na dalju normalizaciju odnosa sa privremenim institucijama samouprave u Prištini“ . Naglašava se, takođe, uloga Ujedinjenih nacija za zaštitu suvereniteta i teritorijalnog integriteta Republike Srbije na ovom prostoru, važna uloga međunarodnog prisustva (UNMIK, KFOR, OEBS i dr.), naročito s obzirom na pokušaje privremenih institucija u Prištini, odnosno „svake vrste inicijative za smanjenje tog prisustva", te "transformaciju naoružanih formacija koje se nazivaju kosovske snage bezbednosti u oružane snage, suprotno Rezoluciji Saveta bezbednosti 1244“ (Strategija RS 2019).

Imajući u vidu cilj i potrebe pisanja ovoga rada, čini se opravdanim navesti $\mathrm{i}$ konkretne bezbednosne izazove, rizike i pretnje prepoznate $\mathrm{u}$ aktuelnoj Strategiji nacionalne bezbednosti, prevashodno stoga što se mnogi od njih $\mathrm{u}$ istoj posmatraju isključivo $\mathrm{u}$ globalnom kontekstu, a svakako da su primarno determinisani konkretnim karakteristikama regionalnog bezbednosnog okruženja. Reč je o: oružanoj agresiji, separatističkim težnjama, jednostranoj protivpravno proglašenoj nezavisnosti Kosova i Metohije, oružanoj pobuni, terorizmu, proliferaciji oružja za masovno uništenje, nacionalnom/etničkom i verskom ekstremizmu, obaveštajnoj delatnosti stranih subjekata i organizovanom kriminalu (Strategija RS 2019). Osim navedenih, prepoznaju se $\mathrm{i}$ „p problemi ekonomskog razvoja, problemi demografskog razvoja, energetska bezbednost, nedovršenje procesa razgraničenja između država nekadašnje SFRJ, posledice elementarnih 
nepogoda i tehničko-tehnoloških nesreća, epidemije i pandemije zaraznih bolesti, narkomanija, visokotehnološki kriminal i klimatske promene“. Konačno, kao jedina pretnja bezbednosti Republike Srbije, značajna u regionalnom kontekstu, koja se pojavljuje u Strategiji nacionalne bezbednosti iz 2019. godine po prvi put jesu masovne ilegalne migracije, na značajnoj poziciji na listi prioriteta izazova, rizika i pretnji bezbednosti Republike Srbije, odmah posle organizovanog kriminala i narkomanije.

Kada je reč o nacionalnim interesima Republike Srbije definisanim $u$ Strategiji nacionalne bezbednosti, čini se osnovanim, u kontekstu regionalne bezbednosti, ukazati na jedan od šest interesa - očuvanje mira i bezbednosti u regionu i svetu, a čiji su ciljevi - doprinos razvoju međunarodnih odnosa u skladu sa međunarodno preuzetim obavezama; doprinos očuvanju međunarodnog mira i bezbednosti; poštovanje međunarodnog prava i unapređenje međunarodnog poverenja; doprinos jačanju regionalne stabilnosti i unapređenje dobrosusedskih odnosa; jačanje svestranih bilateralnih odnosa sa svim državama, uz uvažavanje uzajamnih interesa; te, jačanje aktivnog učešća u radu međunarodnih organizacija (Strategija RS 2019). Interesantno je ukazati još i na način na koji je predstavljen onaj nacionalni interes Republike Srbije koji se odnosi na evropske integracije i članstvo u Evropskoj uniji. Naime, navodi se da ono "dovodi do sveobuhvatnog preoblikovanja društva i privrede, postizanja visokih standarda u svim sferama, jačanja demokratskih institucija i tržišne ekonomije kroz istraživanja i inovacije, rasta izvoza i investicija, rasta zaposlenosti, unapređenja obrazovanja koje će odgovarati tržišnim potrebama, visokog stepena zaštite ljudskih i manjinskih prava, porasta

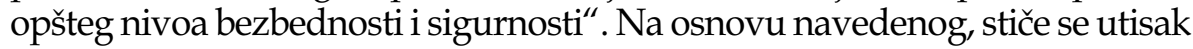
da se evropskim integracijama i članstvom u Evropskoj uniji (odnosno ostvarenjem ovog nacionalnog interesa) ostvaruju gotovo svi nacionalni interesi Republike Srbije. Drugim rečima, sadržaj ovog nacionalnog interesa u sebi obuhvata najveći deo sadržaja svih nacionalnih interesa Republike Srbije sadržanih u Strategiji nacionalne bezbednosti (Stanković 2021a, 100).

\section{ZAKLJUČNA RAZMATRANJA - IMPLEMENTACIJA KONCEPTA REZILIJENTNOSTI U PRISTUP REGIONALNE BEZBEDNOSTI?}

Visok stepen međuzavisnosti na različitim nivoima $u$ izraženo globalizovanom svetu dovodi do „prelivanja“ bezbednosnih pretnji, brišući 
na taj način granicu između lokalnog i globalnog bezbednosnog okruženja. Suočavajući se sa velikim brojem nepoznatih izazova i rizika, kao i asimetričnih pretnji, a u cilju pronalaženja pragmatičnog odgovora na progresivno umrežavanje različitih oblika ugrožavanja nacionalne bezbednosti, dolazi do izraženog regionalnog povezivanja u svim sferama društvenog života. Uvođenjem elemenata koncepta rezilijentnosti u svoje strategije nacionalne bezbednosti (više u: Keković i Dinić 2016), pojedine države govore u prilog potrebi da svoju bezbednost unaprede i podignu na najviši mogući stepen. U uverenju da sposobnost sistema da očuva vitalne funkcije u uslovima ugroženosti, te da se brzo oporavi, odnosno vrati u stanje normalnog funkcionisanja, zavisi od njegovog "imuniteta“ (stečenog $\mathrm{u}$ periodu ispoljene pretnje), mnoge velike sile, eksplicitno ili implicitno, navode faze rezilijentnosti - prevencija, spremnost, reakcija, oporavak - kao mehanizam odgovora na široki spektar nepredvidivih pretnji (Keković i Dinić 2016). Pa ipak, čini se da kreatori nove Strategije nacionalne bezbednosti Republike Srbije zaostaju za ovom praksom, budući da je kontekstualni okvir ove strategije u potpunosti lišen bilo kog elementa rezilijentnosti, bez naznaka da će se i u skorijoj budućnosti isti u bilo kom obimu implementirati.

No, rezimirano, ključna ograničenja koja se nameću kada je reč o kreiranju konceptualnog okvira i metodologije prikladne regionalnom pristupu bezbednosti jesu sledeća:

- Brojnost i raznovrsnost bezbednosnih izazova, rizika i pretnji, naročito prema prirodi i poreklu;

- Kompleksnost - postojanje velikog broja (manje ili više) autonomnih agenata koji međusobno interaguju na najrazličitije načine $u$ pravcu ostvarenja zajedničkog cilja (barem formalno);

- Otežano prepoznavanje svih relevantnih aktera, njihovih međusobnih interakcija (naročito onih prikrivenih), među sobom i sa okruženjem, kao i drugih subjektivnih i objektivnih faktora od uticaja;

- Povratno delovanje „okruženja“ na svakog aktera, dinamički i raznovrsno;

- Neretko prisutna praksa postojanja različitih, često i suprotstavljenih interesa i ciljeva ključnih aktera;

- Ograničene mogućnosti usklađivanja delovanja velikog broja različitih aktera; 
- Izražena dinamika bezbednosnog okruženja - kontinuirane i veoma brze promene;

- Potencijal svake, čak i minimalne promene da veoma brzo dostigne enormne razmere;

- Izražena neizvesnost i nepredvidivost - ograničenja predikcije, naročito dugoročne;

- Delimično ili potpuno osujećivanje realizacije pojedinačnih ciljeva radi ostvarenja primarnog (njegove optimizacije);

- Nemogućnost „izolovanja“ određenih bezbednosnih rizika i, potom, njihovog sintetizovanja zarad kreiranja jednog sveopšteg odgovora i dr. Imajući u vidu prethodno istaknuta ograničenja, za iskorišćavanje punog potencijala implementacije koncepta rezilijentnosti $\mathrm{u}$ regionalni pristup bezbednosti, sugeriše se sledeće:

- Prevazilaženje nametnute podele na metodologiju prirodnih i društvenih nauka, te uvažavanje potrebe za interdisciplinarnim pristupom;

- Utemeljenje u opštoj teoriji sistema, odnosno uvažavanje osnovnih postulata sistemskog pristupa proučavanju bezbednosnih fenomena;

- Kontinuirano i pažljivo praćenje dinamike i promena u okruženju;

- Kreiranje svih relevantnih scenarija potencijalnih bezbednosnih izazova, rizika i pretnji na osnovu identifikovanih indikatora (utvrđivanje čitavog raspona „puteva u budućnost");

- Primena različitih matematičko-operacionih modela;

- Primena teorije determinističkog haosa u cilju prepoznavanja pretećeg „haotičnog" potencijala rizika koji se naziru;

- Primena određenih verzija teorija igara u procesu donošenja strateških odluka;

- Primena različitih multivarijacionih tehnika radi utvrđivanja "skrivenih“ zakonitosti i prepoznavanja "šablona“ pri ispoljavanju određenih bezbednosnih pojava.

Govoreći o potencijalnim benefitima kreiranja rezilijentnog bezbednosnog sistema u regionalnom kontekstu, može se istaći sledeće:

- Prepoznavanje svih relevantnih faktora od uticaja na bezbednosnu dinamiku; 
- Postizanje visokog stepena spremnosti svih relevantnih aktera na različite bezbednosne rizike;

- Omogućavanje njihovog koordinisanog delovanja;

- Snažnija prevencija;

- Jačanje kapaciteta i sposobnosti svih aktera da na adekvatan način odgovore na ispoljene pretnje;

- Mogućnost blagovremenog odgovora na promene u okruženju;

- Kreiranje više različitih potencijalnih rešenja kao odgovor na problemsku situaciju;

- Svođenje nepredvidivosti i neizvesnosti na najmanju moguću meru;

- Blagovremena identifikacija i adekvatna procena bezbednosnih rizika;

- Mogućnost brzog oporavka, uz minimalizovanje štetnih posledica (amortizovanje negativnih uticaja);

- Nastavak normalnog funkcionisanja sistema;

- Redukcija ranjivosti i kritičnosti sistema;

- Mogućnost sistema da iz "krize“ izađe snažniji nego što je prethodno bio ("build back better"); uključujući i mnoge druge.

Dakle, na urgentnu potrebu za preispitivanjem tradicionalnih postulata bezbednosti, te potrebu za kreiranjem dovoljno fleksibilnog i inovativnog metodološkog instrumentarijuma za razumevanje savremenih regionalnih bezbednosnih fenomena može biti odgovoreno usvajanjem različitih sadržaja koncepta rezilijentnosti, preuzetih iz različitih naučnih disciplina. Kvalitativno, rezilijentnost poseduje značajan potencijal da bude valjan konceptualni okvir, primenljiv na regionalnu bezbednost. Sa druge strane, kvantifikacijom rezilijentnosti i izradom valjane skale, a na osnovu konkretnih osobenosti i okolnosti karakterističnih za bezbednosnu dinamiku određenih regiona, može se vršiti analiza i ocena stanja bezbednosti istih. Korišćenjem komparativnog ili protektivnog modela rezilijentnosti (kako protektivno-stabilizirajućeg tako i protektivnoreaktivnog), uključujući i model izazova (te pripadajući mu model inokulacije), a uz oslonac na promotivne i protektivne faktore, mogu se vršiti prilično precizne analize stanja bezbednosti u nekom regionu. Najzad, kreiranjem rezilijentnog regionalnog bezbednosnog sistema, odnosno izgradnjom sva tri (ili četiri) kapaciteta rezilijentnosti - apsorptivni, adaptivni i restorativni (poželjno i prediktivni) - eliminisaće se nivo njegove 
ranjivosti, učiniće se otpornijim i spremnijim na aktuelne i buduće raznolike bezbednosne izazove, rizike i pretnje.

\section{BIBLIOGRAFIJA}

Acharya, Amitav. 2007. "The emerging regionalarchitecture of world politics". World Politics 59 (4): 629-652.

Adler, Emanuel. 1997. “Imagined (security) communities: cognitive regions in international relations". Millennium-Journal of International Studies 26 (2): 249-277.

Adler, Emanuel and Michael Barnett, eds. 1998. Security communities. Cambridge: Cambridge University Press.

Anderson, Benedict. 1983. Imagined communities: Reflections on the origin and spread of nationalism. London: Verso Books.

Barasa, Edwine, Rahab Mbau and Lucy Gilson. 2018. "What is Resilience and How It Can be Nurtured? A Systematic Review of Empirical Literature on Organizational Resilience". International Journal of Health Policy Management 7 (6): 491-503.

Beeson, Mark. 2005. "Rethinking regionalism: Europe and East Asia in comparative historical perspective". Journal of European Public Policy 12 (6): 969-985.

Buzan, Barry. 1983. People, States, and Fear: The National Security Problem in International Relations. Hemel Hempstead: Harvester Wheatsheaf.

Buzan, Barry, Ole Wæver and Jaap De Wilde. 1998. Security: a new framework for analysis. Boulder: Lynne Rienner Publishers.

Cantori, Louis and Steven Spiegel. 1970. The international politics of regions. New Jersey: Prentice Hall.

Carver, Charles. 1998. "Resilience and thriving: Issues, model, and linkages". Journal of social issues 54 (2): 245-266.

Feld, Werner and Gavin Boyd. 1980. "The comparative Study of International Regions". In: Comparative Regional Systems: West and East Europe, North America, The Middle East and Developing Countries, edited by Werner J. Feld and Gavin Boyd, 3-17. New York: Pergamon Press. 
Fergus, Stevenson and Marc Zimmerman. 2005. "Adolescent resilience: A framework for understanding healthy development in the face of risk". Annual Review of Public Health 26: 399-419.

Fraccascia, Lucca, Ilaria Giannoccaro and Vito Albino. 2018. "Resilience of complex systems: State of art and directions for further research". Complexity 2018: 1-44.

Hantington, Semjuel. 2000. Sukob civilizacija i preoblikovanje svetskog poretka. Podgorica: CID.

Hettne, Björn and Fredrik Söderbaum. 2000. "Theorising the rise of regionness". New Political Economy 5 (3): 457-472.

Hettne, Björn. 2005. “Beyond the 'New' Regionalism”. New Political Economy 10 (4): 543-571.

Hurrell, Andrew. 2007. "One world? Many worlds? The place of regions in the study of international society". International Affairs 83 (1): 127-146.

Janev, Igor. 2011. „Pojam i definicija bezbednosti i teorija relacionizma u razmatranju bezbednosti“. Politicka revija 3:365-386.

Kapor, Predrag. 2017. „,Teorije igara: Sistemski pristup i razvoj“. Megatrend revija 14 (1): 253-282.

Katzenstein, Peter. 2005. A World Regions: Asia and Europe in the American Imperium. Ithaca \& New York: Cornell University Press.

Keković, Zoran, Goran Glišić i Nenad Komazec. 2009. „Pristup metodologiji procene rizika“. Nauka, bezbednost, policija 3: 4103-4116.

Keković, Zoran, Zoran Dragišić i Vladimir Ninković. 2014. “Towards Resilient Critical Infrastructure against Terrorism Risk". In: Comprehensive approach as ,sine qua non" for critical infrastructure protection, edited by Denis Čaleta and Vesela Radović, 45-59. Amsterdam: IOS Press.

Keković, Zoran i Jelena Dinić. 2016. „Transformacija nacionalne bezbednosti - rezilijentnost u strategijama bezbednosti velikih sila kao odgovor na globalne bezbednosne pretnje". Zbornik radova Pravnog fakulteta u Novom Sadu 50 (4): 1141-1156.

Keković, Zoran i Vladimir Ninković. 2020. “Towards a conceptualization of resilience in security studies". Srpska politička misao 67 (1): 153-175.

Kellert, Stephen. 1993. In the Wake of Chaos: Unpredictable Order in Dnamical Systems. Chicago: University of Chicago Press. 
Lipovac, Milan. 2016. Nacionalna bezbednost Republike Srbije u regionalnom bezbednosnom potkompleksu Zapadni Balkan. Doktorska disertacija. Fakultet bezbednosti, Univerzitet u Beogradu.

Longstaff, Patricia, Nicholas Armstrong, Keli Perrin, Whitney Parker and Matthew Hidek. 2010. "Building Resilient Communities: A Preliminary Framework for Assessment". Homeland Security Affairs 6 (3): 1-23.

Luthar, Suniya, Dante Cicchetti and Bronwyn Becker. 2000. “The construct of resilience: A critical evaluation and guidelines for future work". Child Development 71 (3): 543-562.

Mansfield, Edward and Helen Milner. 1999. “The new wave of regionalism”. International organization 53 (3): 589-627.

Masten, Ann. 2014. "Global perspectives on resilience in children and youth". Child development 85 (1): 6-20.

Mattli, Walter. 1999. The logic of regional integration: Europe and beyond. Cambridge: Cambridge University Press.

National Infrastructure Advisory Council. 2009. Critical Infrastructure Resilience: Final Report and Recommendations. USA: Cybersecurity and Infrastructure Security Agency.

Nye, Joseph, ed. 1968. International regionalism: readings. Brown: Little.

Neumann, Iver. 1994. "A region-building approach to Northern Europe". Review of International Studies 20 (1): 53-74.

Nojman, Iver. 2011. Upotrebe drugog - istok u formiranju evropskog identiteta. Beograd: Službeni glasnik.

[NSS USA] National Security Strategy of the United States of America. 2010. (May 2010). https://obamawhitehouse.archieves.gov/sites/default/ files/rss_viewer/national_security_strategy.pdf

Petrović, Slavica. 2006. Sistemsko mišljenje, sistemske metodologije. Kragujevac: Ekonomski fakultet u Kragujevcu.

Pike, Andy, Stuart Dawley and John Tomaney. 2010. “Resilience, Adaptation and Adaptability". Cambridge Journal of Regions, Economy and Society 3 (1): 59-70.

Potkonjak-Lukić, Brankica i Stanislav Stojanović. 2016. „Vojna neutralnost Republike Srbije u svetlu teorije determinističkog haosa“. U: Uticaj vojne neutralnosti Srbije na bezbednost $i$ stabilnost u Evropi, uredio Srđan Korać, 
97-117. Beograd: Institut za međunarodnu politiku i privredu i Hanns Seidel Stiftung-Kancelarija za Srbiju i Crnu Goru.

Risk Steering Committee. 2008. DHS Risk Lexicon. USA: U.S. Department of Homeland Security.

Roberts, Siobhan. 2017. "Remembering Lotfi Zadeh, the inventor of fuzzy logic", The New Yorker, September 19. https://newyorker.com/tech/ annals-of-technology/remembering-lotfi-zadeh-the-inventor-of-fuzzylogic

Russet, Bruce. 1967. International regions and the international system. A Study in Political Ecology. Chicago: Rand McNally.

Saperstein, Alvin. 1997. “The Prediction od Unpredictability: Applications of the New Paradigm of Chaos in Dynamical Systems to the Old Problem of the Stability of a System of Hostile Nations". In: Chaos Theory in the social science: foundations and applications, edited by Douglas Kiel and Euel Elliot, 139-163. Michigan: University of Michigan Press.

Simonović, Slobodan. 2011. System Approach to Management of Disasters: Methods and Applications. New Jersey: Hoboken.

Singer, David. 1961. "The level-of-analysis problem in international relations". World Politics 14 (1): 77-92.

Stanković, Nevena. 2020b. „Kritički prilog diskusiji o strategiji Republike Srbije u upravljanju prvom fazom epidemije COVID-19“. Kultura polisa XVII (Pos. 2): 179-194.

Stanković, Nevena. 2021a. „Koncept ljudske bezbednosti u Strategiji nacionalne bezbednosti iz 2019. godine - korak unazad“. Politika nacionalne bezbednosti XII (20): 75-109.

Stanković, Nevena. 2020a. „Implikacije formalnih teorija bezbednosti na upravljanje COVID-19 krizom“. Godišnjak Fakulteta bezbednosti 2020: 25-40.

Stanković, Nevena. 2021b. „Upravljanje epidemijom COVID-19 u svetlu opšte teorije sistema". Zbornik radova Pravnog fakulteta u Novom Sadu (fothcoming).

[Strategija RS] Strategija nacionalne bezbednosti Republike Srbije. 2019. Službeni glasnik RS, No. 94 (Decembar 27). https://www.pravnoinformacioni-sistem.rs/SlGlasnikPortal/eli/rep/sgrs/skupstina/ strategija/2019/94/2 
Thompson, William. 1973. "The regional subsystem: a conceptual explication and a propositional inventory". International Studies Quarterly 17 (1): 89-117.

[UNDRR] United Nations Office for Disaster Risk Reduction. 2008. Disaster Preparedness for Effective Response: Guidance and Indicator Package for Implementing Priority Five of the Hyogo Framework. New York and Geneva: United Nations.

U.S. Department of Defense. 2010. Quadrennial Defense Review Report. USA: U.S. Department of Defense.

Väyrynen, Raimo. 1984. “Regional conflict formations: an intracable problem of international relations". Journal of Peace Research 21 (4): 337-359.

Väyrynen, Raimo. 1992. "Regional Systems and International Relations". In: Approaches to the Study of International Political Economy, edited by Helena Lindhoch, 119-137. Gothenburg: University of Gothenburg, Padrigu Papers.

Väyrynen, Raimo. 2003. "Regionalism: old and new". International Studies Review 5 (1): 25-51.

Wolraich, Mark, Paul Dworkin, Denis Drotar and Ellen Perrin. 2007. Developmental-Behavioral Pediatrics: Evidence and Practice. Edinburgh, London and Oxford: Elsevier Health Sciences.

Yalem, Ronald. 1977. "The level-of-analysis problem reconsidered". Year Book of World Affairs 31 (3): 306-326. 


\section{RESILIENCE: A CONCEPTUAL FRAMEWORK AND METHODOLOGICAL TOOL FOR ASSESSING AND IMPROVING REGIONAL SECURITY?}

Abstract: In recent decades, the obvious transformation of security challenges, risks and threats makes it necessary to reconceptualize the existing traditional security paradigms. One of the key shortcomings of modern security studies is the lack of appropriate methodological tools for analysis, assessment and evaluation of security, whether at the level of the state, region or the international order. One of the more frequent terms in the terminology of various sciences and scientific disciplines is the notion of "resilience". The use of this term in security studies, especially here, is still in its infancy. Nevertheless, it seems that the benefits of its use, to some extent modified and adapted to the needs in the field of security, would be numerous. First, resilience in its qualitative (descriptive) form can serve as a valid conceptual framework. Furthermore, by attempting to quantify it (by creating appropriate indicators and creating a scale of resilience), potentially double effects could be achieved: analysis and assessment of the security of a region, but also reducing its vulnerability/increasing resilience, i.e., strengthening the resilience of the region to the existing and potential future security risks and crises. The use of resilience as a methodological tool could be achieved by synthesizing relevant resilience contents taken from different scientific disciplines, with its stronghold in systems theory, and by introducing new contents characteristic of security needs, i.e., arising from the peculiarities of contemporary regional security challenges, risks and threats.

Keywords: regional security, resilience, methodology, vulnerability, systems theory. 